\title{
Oral Ointment Dosage Form
}

National Cancer Institute

\section{Source}

National Cancer Institute. Oral Ointment Dosage Form. NCI Thesaurus. Code C91169.

An ointment intended for administration through the mouth. 